\title{
Effect of pressure and temperature on the availability of lysine in meat and bone meal as determined by slope-ratio assays with growing pigs, rats and chicks and by chemical techniques
}

\author{
BY E.S. BATTERHAM AND R. E. DARNELL* \\ Department of Agriculture, Agricultural Research Centre, \\ Wollongbar, New South Wales 2480, Australia \\ AND L. S. HERBERT \\ CSIRO Meat Research Laboratory, Cannon Hill, Queensland 4170, Australia \\ AND E. J. MAJOR \\ Department of Agriculture, Agricultural Station, Seven Hills, \\ New South Wales 2147, Australia
}

(Received 17 July 1985 - Accepted 30 September 1985)

1. The availability of lysine for pigs, rats and chicks was determined using samples of meat and bone meal (MBM) subjected to different pressure and temperature treatments during dry-rendering processing. The relation between slope-ratio estimates and three chemical tests for estimating 'available' lysine was assessed.

2. The availability of lysine (proportion of total) for pigs was 0.97 in the control. Pressure ( $275 \mathrm{kPa}$ gauge, $141^{\circ}$, for $30 \mathrm{~min}$ ) in the early stage of rendering reduced availability to 0.74 and, in the late stage, to 0.46 . Maintaining the final temperature at $125^{\circ}$ for $4 \mathrm{~h}$ had little effect $(0 \cdot 84)$ whereas a higher temperature of $150^{\circ}$ for $4 \mathrm{~h}$ reduced availability to $0 \cdot 38$.

3. Availability estimates for rats were lower than those of the pig, ranging from 0.88 in the control to 0.21 for the high-temperature treatment $\left(150^{\circ}\right.$ for $\left.4 \mathrm{~h}\right)$. The effects for temperature were similar to those for the pig, whereas the effect of pressure was equally detrimental in both the early and late stages $(0.45$ and 0.43 respectively).

4. For chicks, availability estimates were similar to those for the pig for the control $(0.93)$ and the two temperature treatments $\left(0.86\right.$ and 0.31 for the $125^{\circ}$ and $150^{\circ}$ treatments respectively). The chick was less susceptible to the effect of pressure applied to the MBM (0.78 and 0.63 for the early- and late-stage treatments respectively).

5. Values for the indirect- and direct-1-fluoro-2,4-dinitrobenzene-(FDNB)-'available'-lysine assays decreased from 0.86 and 0.74 to 0.57 and 0.54 for the control and $150^{\circ}$ for $4 \mathrm{~h}$ treatments respectively, indicating that approximately half the reduced availability involved reactions with the $\epsilon$-amino group of lysine. There was little relation between the FDNB values and lysine availability for the treatments involving changes in pressure.

6. There was little or no relation between dye-binding capacity of the meals, as assessed by the Acid Orange-12 dye-binding procedure (Hurrell et al. 1979), and lysine availability for the three species.

Previous work indicated that lysine availability (proportion of total) in meat meal (MM) and meat and bone meal (MBM) varied from 0.48 to 0.88 for pigs and rats, and from 0.68 to 0.88 for chicks (Batterham et al. 1986). This variation appeared to be unrelated to the chemical composition of the meals. Although the range in lysine availabilities for pigs and rats were similar, there was little agreement between the two species for individual meals. This species difference in ability to utilize lysine may reflect differences in the mechanisms of damage induced by the temperature or pressure applied, or both, during dry-rendering processing of animal tissue and bones.

The differences in lysine availability in the MMs and MBMs for pigs was not detected by the indirect-(Roach et al. 1967) nor direct- (Carpenter, 1960) 1-fluoro-2,4-dinitrobenzene(FDNB)-'available'-lysine assays, indicating that reactions involving the $\epsilon$-amino group of lysine were not a major cause of reduced availability.

\footnotetext{
* Present address: Agricultural Research and Advisory Station, Grafton, New South Wales 2460, Australia.
} 
The objectives of the present study were to investigate the effects of pressure and temperature in rendering on the availability of lysine in MBM for pigs, rats and chicks. In addition, the relation between three chemical assays for predicting 'available' lysine (the indirect- and direct-FDNB assays and the Acid Orange-12 dye-binding procedure (Hurrell et al. (1979)) and pig, rat and chick response was assessed.

\section{EXPERIMENTAL}

\section{Preparation of $M B M$ treatments}

Processing of offal material to MBM is commonly carried out in batch, dry-rendering cookers, with the rendering process taking place in two stages (Herbert et al. 1974). In the 'early' stage, the contents of the cookers increase in temperature to about $100^{\circ}$ soon after charging, and water begins to boil off. Throughout the early stage, the cooker contents comprise a liquid phase of molten tallow and water and a solid phase of water-wet meat tissue and bone. Initially, water predominates in the liquid phase but, as water continues to boil off, the tallow predominates, and the process enters a 'late' stage. During the early stage, the temperature of the contents remains at about $100^{\circ}$, but during the later stage, the temperature progressively increases, until all water is removed from the liquid phase, and the solids commence drying by a 'deep frying' process. The desired end-point, when the water content of the solids in the cooker has fallen to about $60 \mathrm{~g} / \mathrm{kg}$, is reached when the temperature of the contents has increased to about $125^{\circ}$. Pressure applied in the early or late stage (to achieve, for example, hydrolysis of wool and hair) results in a substantial increase in the temperature of the contents.

The objectives of the treatments selected were to examine the effect of pressure, and of continued heating for $4 \mathrm{~h}$ after the end-point at normal end-point temperature $\left(125^{\circ}\right)$ or high temperature $\left(150^{\circ}\right)$.

Experimental meals were produced in a small-batch, dry-rendering cooker capable of producing about $100 \mathrm{~kg}$ finished meal per cook. Total preparation and processing time for each cook was about $5 \mathrm{~h}$ and since $300 \mathrm{~kg}$ of meal were required for each of five treatments, processing was extended over several weeks. It was therefore impossible to use the same raw material for each cook. The problem of variation in raw material confounding treatment responses was avoided by producing approximately 2 tonnes MBM from a commercial wet-rendering plant. Previous work had shown that this product was of high indirect-FDNB-lysine availability and was able to be stored under cool dry conditions without degradation. The wet-rendered meal was thoroughly blended to provide a uniform starting material, which was then reconstituted with tallow and water and placed in the cooker for processing of experimental treatments. The following experimental batches were produced:

T1. A sample of the wet-rendered meal which was used as a control.

$T 2$. This tested the effect of pressure during the early stage of MBM processing. Three batches, each of $80 \mathrm{~kg}$ wet-rendered meal, $80 \mathrm{~kg}$ water and $50 \mathrm{~kg}$ tallow were rendered in the cooker. Each batch was cooked under atmospheric pressure $\left(100^{\circ}\right)$ for $10 \mathrm{~min}$, pressure applied $\left(275 \mathrm{kPa}\right.$ gauge, $\left.141^{\circ}\right)$ for $30 \mathrm{~min}$, pressure released and cooking continued under atmospheric pressure for about $2 \mathrm{~h}$ to an end-point of $125^{\circ}$. Cooked solids were centrifuged to remove excess tallow. The tallow-wet solids were comminuted and the product from the three batches thoroughly mixed and blended.

T3. This tested the effect of pressure applied during the late stage of MBM processing. Three batches, as in T2, were cooked under atmospheric pressure for about $2 \mathrm{~h}$, pressure applied $\left(275 \mathrm{kPa}\right.$ gauge, $141^{\circ}$ ) for $30 \mathrm{~min}$, pressure released and cooking continued under 
atmospheric pressure for about $30 \mathrm{~min}$ to $125^{\circ}$ final temperature. Batches of cooked solids were centrifuged, comminuted and blended as for $\mathrm{T} 2$.

T4. This examined the effect of extending a final temperature of $125^{\circ}$ for $4 \mathrm{~h}$. Three batches, each of $80 \mathrm{~kg}$ wet-rendered meal and $50 \mathrm{~kg}$ tallow, were cooked under atmospheric pressure to $125^{\circ}$ and heating continued at $125^{\circ}$ for $4 \mathrm{~h}$. Batches of cooked solids were centrifuged, comminuted and blended as for $\mathrm{T} 2$.

T5. This examined the effect of extending a final temperature of $150^{\circ}$ for $4 \mathrm{~h}$. Preparation was similar to that for T4 except for the final temperature of $150^{\circ}$.

In order to verify that the initial wet-rendering of the meal had no significant effect on the experimental treatments, a small quantity of the raw material used to produce the wet-rendered meal was processed through the cooker. Three processing treatments were imposed. Firstly, the fresh raw material was rendered under atmospheric pressure to an end-point of $125^{\circ}$. At this stage, approximately one-third of the contents was released from the cooker. The remaining meal was then processed at $125^{\circ}$ for an additional $4 \mathrm{~h}$ when about half the material was discharged. The remaining material was then processed for an additional $4 \mathrm{~h}$ at $150^{\circ}$. The three meals were centrifuged and comminuted to give meals designated DR1, DR2 and DR3 respectively. These three meals were used in slope-ratio assays with rats and chicks.

The chemical compositions of the eight experimental batches are presented in Table 1.

\section{Slope-ratio assays}

Slope-ratio assays were used to determine the availability of lysine in the protein concentrates for pigs, rats and chicks. For these assays, diets are formulated to contain graded levels of standard and test lysine. Linear regression coefficients of response (say food conversion efficiency) to increasing dose level of test protein and standard lysine are calculated and the ratio of the test protein's linear regression coefficient to the standard lysine's linear regression coefficient provides the potency of the lysine in the test protein. In our assays the dose levels for the test proteins were formulated to contain the same total lysine as that of the standard lysine doses so that the potency estimate for lysine in the test protein was an expression of lysine availability as a proportion of total lysine. The statistical analysis of the slope-ratio assays were as outlined in Chapter 7 of Finney (1964).

In the statistical analyses of the slope-ratio assays, there are a number of criteria to be tested to try to ensure that the responses are due to the test amino acids and are not influenced by other dietary factors (Finney, 1964). The response to the standard amino acid is examined to determine if it passes through the basal diet (designated blanks). Similarly, the response to each test protein is examined to ensure that it passes through a common origin with the standard amino acid response (called test for intersection). The responses to both the standard amino acid and the test proteins are also examined to determine if there is any curvature (quadratic, etc.) in the responses. This could be due to either depressing (if negative curve) or stimulatory (if positive curve) effects of nutrients contributed by the test protein. If the above tests are not significant, then the responses are considered statistically valid and the availability estimates calculated. The degrees of freedom used in the analysis are given by Batterham et al. (1984).

There are a number of criteria that can be used to assess response. For pigs and rats, food conversion efficiency (FCE) on a carcass basis is preferred as it takes into account differences in both food intake and gut contents (Batterham et al. 1979, 1981, 1984). For chicks, FCE on a live-weight basis was chosen as there was no apparent advantage in expressing results on a fasted basis (Major \& Batterham, 1981). 
Table 1. Composition ( $\mathrm{g} / \mathrm{kg}$ air dry basis) of the wheat, wheat gluten and eight batches of meat and bone meal*

\begin{tabular}{|c|c|c|c|c|c|c|c|c|c|c|}
\hline & Wheat & $\begin{array}{l}\text { Wheat } \\
\text { gluten }\end{array}$ & $\mathrm{T} 1$ & $\mathrm{~T} 2$ & $\mathrm{~T} 3$ & $\mathrm{~T} 4$ & T5 & DR1 & DR2 & DR3 \\
\hline \multicolumn{11}{|l|}{ Crude protein } \\
\hline Dry matter & 915 & 913 & 950 & 960 & 965 & 945 & 957 & 964 & 970 & 982 \\
\hline $\begin{array}{l}\text { Light petroleum } \\
\text { (b.p. } 40-60^{\circ} \text { ) extract }\end{array}$ & 18 & 6 & 91 & 196 & 203 & 222 & 198 & 147 & 146 & 156 \\
\hline Crude fibre & 41 & - & - & - & - & - & - & - & - & - \\
\hline Ash & 16 & 9 & 216 & 186 & 189 & 173 & 196 & 222 & 235 & 250 \\
\hline Bone & - & - & 279 & 186 & 225 & 222 & 254 & 267 & 284 & 324 \\
\hline Calcium & - & - & 76 & 68 & 71 & 67 & 70 & 75 & 79 & 88 \\
\hline Acid-insoluble ash & 0.6 & 0 & 10 & $9 \cdot 3$ & $8 \cdot 6$ & $9 \cdot 3$ & $9 \cdot 3$ & $\ldots$ & - & - \\
\hline Gross energy $(\mathrm{MJ} / \mathrm{kg}$ ) & $16 \cdot 5$ & $21 \cdot 4$ & $18 \cdot 3$ & $21 \cdot 4$ & $22 \cdot 4$ & $21 \cdot 8$ & $20 \cdot 9$ & $19 \cdot 2$ & $19 \cdot 5$ & $19 \cdot 3$ \\
\hline \multicolumn{11}{|l|}{$\begin{array}{l}\text { Essential amino } \\
\text { acids }(\mathrm{g} / 16 \mathrm{~g} \mathrm{~N})\end{array}$} \\
\hline Threonine & 3.4 & 2.8 & 3.8 & 3.7 & 3.9 & 3.9 & $4 \cdot 1$ & $4 \cdot 2$ & $4 \cdot 1$ & $3 \cdot 4$ \\
\hline Valine & 3.9 & 3.9 & $4 \cdot 5$ & $4 \cdot 3$ & $4 \cdot 7$ & $4 \cdot 5$ & $4 \cdot 4$ & $4 \cdot 5$ & $4 \cdot 0$ & $4 \cdot 3$ \\
\hline Cystine & 0.8 & 2.8 & 1.9 & $-t$ & - & $1 \cdot 3$ & - & $2 \cdot 1$ & $1 \cdot 3$ & - \\
\hline Methionine & 1.2 & 1.5 & 1.7 & 1.9 & 1.6 & 1.6 & 1.6 & 1.5 & 1.3 & 1.4 \\
\hline Isoleucine & $3 \cdot 3$ & 3.5 & 3.0 & 3.0 & $3 \cdot 1$ & 3.0 & 3.4 & $3 \cdot 2$ & $2 \cdot 8$ & $3 \cdot 2$ \\
\hline Leucine & $7 \cdot 0$ & 7.0 & 6.7 & 6.7 & $7 \cdot 0$ & 6.7 & $7 \cdot 4$ & 6.9 & $6 \cdot 3$ & $6 \cdot 3$ \\
\hline Tyrosine & $3 \cdot 3$ & 3.2 & 2.6 & 2.8 & $3 \cdot 0$ & $2 \cdot 6$ & 2.8 & $3 \cdot 0$ & 2.5 & $2 \cdot 7$ \\
\hline Phenylalanine & 4.6 & $4 \cdot 2$ & 3.7 & $3 \cdot 2$ & 3.5 & 3.4 & 3.6 & 3.9 & $3 \cdot 2$ & $3 \cdot 4$ \\
\hline Histidine & $2 \cdot 6$ & 2.0 & 1.7 & 1.5 & 1.6 & 1.7 & $1 \cdot 3$ & 1.7 & $1 \cdot 6$ & 1.4 \\
\hline Lysine & 3.0 & 1.6 & 5.8 & $5 \cdot 3$ & $5 \cdot 0$ & $5 \cdot 3$ & $5 \cdot 1$ & $5 \cdot 4$ & 4.9 & $4 \cdot 5$ \\
\hline Arginine & 4.4 & - & - & - & - & - & - & - & - & - \\
\hline
\end{tabular}

* For information on processing treatment, see page 442.

$\uparrow$ Not adequately resolved.

Pig slope-ratio assay

Diets. The five experimental batches (T1-T5) were assayed in the one experiment. This involved the use of thirty-one diets: the basal diet (blanks), five diets to determine the pigs' response to standard lysine and twenty-five for the five experimental batches (five for each batch). The basal diet (Tables 1 and 2) was formulated using a medium-protein wheat (Condor cultivar) which, in combination with the wheat gluten, supplied adequate quantities of all amino acids except lysine, which was added to bring the basal level up to $5.5 \mathrm{~g} / \mathrm{kg}$, and methionine, which was added to ensure adequacy according to the estimates of Lewis \& Cole (1976). The five levels of lysine used to determine the pigs' response to standard lysine were in $0.5-\mathrm{g}$ increments of L-lysine $/ \mathrm{kg}$ and were obtained by the addition to the basal diet of L-lysine monohydrochloride, anhydrous, feed grade, supplied by Toray Industries Inc., Japan. The experimental batches were incorporated into the basal diets to provide five levels of total lysine, again in $0.5-\mathrm{g} / \mathrm{kg}$ increments, at the expense of wheat starch. The quantity of tricalcium phosphate was reduced as the level of MBM in each diet increased, to maintain diets of similar calcium and phosphorus contents.

The digestible energy content of the dietary components was calculated using results of previous determinations at this Agricultural Research Centre or literature values. The tallow contents of batches T2-T5 were higher than that of T1. This may have been due to the effect of excess heat on the meals. Previous work (Batterham, 1973) indicated low digestible energy in over-processed MM of similar high-oil content. Accordingly, this was taken into account 
Table 2. Composition $(\mathrm{g} / \mathrm{kg}$ ) of the basal diets used for the slope-ratio assays with pigs, rats and chicks

\begin{tabular}{lccc} 
& Pigs & Rats & Chicks \\
\hline Wheat & 790 & 650 & 610 \\
Wheat gluten & 60 & 100 & 140 \\
Amino acids* & $1 \cdot 35$ & $2 \cdot 4$ & $13 \cdot 9$ \\
Mineral and vitamin premix & $5 \cdot 5$ & 5 & $8 \cdot 5$ \\
Tricalcium phosphate & 21 & 15 & 30 \\
Solkafloc & 15 & -35 & $27 \cdot 5$ \\
Oilt & 15 & $192 \cdot 6$ & $170 \cdot 1$ \\
Wheat starch & $92 \cdot 15$ & \\
\hline
\end{tabular}

* Contributed the following ( $/ \mathrm{kg}$ diet) for pigs: L-lysine monohydrochloride $1 \cdot 15$, DL-methionine $0 \cdot 2$; for rats: L-lysine monohydrochloride $0 \cdot 4$, DL-methionine $1 \cdot 5$, L-tryptophan $0 \cdot 5$; for chicks: L-threonine $1 \cdot 6$, DL-methionine 2.5, L-isoleucine 1.2, DL-tryptophan 1.6, L-arginine monohydrochloride 7 .

$\dagger$ Contributed the following (/kg diet) for pigs: iron $60 \mathrm{mg}$, zinc $100 \mathrm{mg}$, manganese $30 \mathrm{mg}$, copper $5 \mathrm{mg}$, iodine $2 \mathrm{mg}$, selenium $0 \cdot 15 \mathrm{mg}$, sodium chloride $2 \cdot 8 \mathrm{~g}$, retinol equivalent $960 \mu \mathrm{g}$, cholecalciferol $12 \mu \mathrm{g}, \alpha$-tocopherol $20 \mathrm{mg}$, thiamin $1.5 \mathrm{mg}$, riboflavin $3 \mathrm{mg}$, nicotinic acid $14 \mathrm{mg}$, pantothenic acid $10 \mathrm{mg}$, pyridoxine $2.5 \mathrm{mg}$, cyanocobalamin $15 \mu \mathrm{g}$, pteroylmonoglutamic acid $2 \mathrm{mg}$, choline $500 \mathrm{mg}$, ascorbic acid $10 \mathrm{mg}$, biotin $0.1 \mathrm{mg}$, olaquindox $25 \mathrm{mg}$; for rats: as for pigs except cholecalciferol $27 \mu \mathrm{g}, \alpha$-tocopherol $35 \mathrm{mg}$, pyridoxine $7 \mathrm{mg}$ and olaquindox deleted; for chicks: manganese dioxide $96 \mathrm{mg}$, zinc oxide $60 \mathrm{mg}$, sodium molybdate $0.6 \mathrm{mg}$, cupric oxide $7.2 \mathrm{mg}$, iodine $1 \mathrm{mg}$, sodium chloride $2.5 \mathrm{~g}$, retinol equivalent $3.6 \mathrm{mg}$, cholecalciferol $54 \mu \mathrm{g}, \alpha$-tocopherol equivalent $3 \mathrm{mg}$, menadione-sodium bisulphite $1.4 \mathrm{mg}$, riboflavin $4.8 \mathrm{mg}$, pantothenic acid $6.6 \mathrm{mg}$, pyridoxine $4.8 \mathrm{mg}$, pteroylmonoglutamic acid $1.2 \mathrm{mg}$, nicotinic acid $24 \mathrm{mg}$, biotin $60 \mu \mathrm{g}$, cyanocobalamin $9 \mu \mathrm{g}$, choline chloride $120 \mathrm{mg}$, ethoxyquin $150 \mathrm{mg}$.

$\ddagger$ For pigs, soya-bean oil; for rats, maize oil; for chicks, blended vegetable oil.

when estimating the digestible energy content in T2 to T5. Dietary energy was maintained at $14 \cdot 2 \mathrm{MJ}$ digestible energy $/ \mathrm{kg}$ diet using soya-bean oil and wheat starch as non-protein energy sources. In order to verify the digestible energy formulations, the digestible energy content of the diets was determined using the acid-insoluble ash content in the diets and faeces as an indicator of digestibility (McCarthy et al. 1977).

Animals and procedures. The pigs were blocked on 7-week weight, sex and position in the experimental facilities. There were four randomized complete blocks, two containing males and two females, all of the Large White breed. Thus there were four pigs per diet except for diets 3-6 (1-2.5 g/ kg of standard lysine) where an extra pig was allocated per diet. The 128 pigs were penned individually and water supplied by 'nipple' drinkers. Dietary treatments were introduced when the pigs reached $20 \mathrm{~kg}$ live weight.

The diets were offered at a daily rate of $1 \mathrm{~kg}$ at $20 \mathrm{~kg}$ live weight, with $100 \mathrm{-g}$ increments $/ 2.5 \mathrm{~kg}$ live-weight gain. The pigs were fed eight times daily, at intervals of $3 \mathrm{~h}$, with a solenoid-controlled automatic frequent feeder to ensure the utilization of added free amino acids (Batterham \& Murison, 1981). The food was offered dry. Rations were adjusted after the weekly weighings of the pigs.

The pigs were slaughtered after reaching a minimum weight of $45 \mathrm{~kg}$ and hot eviscerated carcass weights recorded. The ham was dissected and the lean content used as an indicator of carcass leanness. Pig response was assessed in terms of carcass gain $/ \mathrm{d}$ ( $\mathrm{kg}$ hot carcass weight $-(\mathrm{kg}$ initial live weight $\times 0.69) /$ period (d) on experiment $)$ and FCE on a carcass basis ( $\mathrm{kg}$ hot carcass weight $-(\mathrm{kg}$ initial live weight $\times 0.69) / \mathrm{kg}$ food intake). The factor of 0.69 for estimated carcass weight was previously determined with ten piglets (five males and five females) slaughtered at $20 \mathrm{~kg}$ live weight.

The results for FCE on a carcass basis were analysed by the slope-ratio technique of Finney (1964) for multiple assays. 
The results for lean content of the hams were regressed against lysine for each protein concentrate. This analysis was conducted to determine if there was any effect of dietary lysine concentration on lean deposition.

The results from the acid-insoluble ash estimation of digestible energy were analysed by analysis of variance and the values for each test protein examined for linear and quadratic responses.

\section{Rat slope-ratio assay}

Diets. Single separate assays were conducted for each protein concentrate. A total of seven diets were used for each assay: the basal diet (blanks), three diets to determine the rats' response to standard lysine and three diets to determine the rats' response to the MBMs. The basal diet (Table 2) was formulated using the same wheat and gluten as for the pigs which supplied adequate levels of all amino acids except lysine, which was added to bring the basal level up to $4.7 \mathrm{~g} / \mathrm{kg}$, methionine and tryptophan. The latter two were added to ensure adequacy according to estimates of the (US) National Research Council (1972). The three levels of L-lysine used to determine the rats' response to standard lysine were 0.75 , 1.5 and $2.25 \mathrm{~g} / \mathrm{kg}$ (same batch of lysine as used for the pig assay). The MBMs were incorporated into the diets to supply the same three levels of total lysine as used to determine the standard lysine response. This was done at the expense of wheat starch. The quality of tricalcium phosphate was reduced as the level of MBM in each diet increased to maintain diets of similar calcium and phosphorus content.

Animals and procedure. For the rat assays, two female and two male albino rats, approximately 24-26-d-old, were used per dose and were blocked on the basis of litter and sex (block size seven). The rats were individually caged in a room where the temperature and relative humidity were maintained at $21 \pm 1^{\circ}$ and $50 \pm 5 \%$ respectively. Lighting was provided for $12 \mathrm{~h}$ daily. Food was supplied in 'self-feeders'.

At the completion of a $14 \mathrm{~d}$ test, the rats were weighed, killed with chloroform, and the alimentary tract, heart and lungs removed. The weight of the eviscerated carcass was recorded. Performance was assessed in terms of carcass gain ( $\mathrm{g}$ eviscerated carcass weight $-(\mathrm{g}$ initial live weight $\times 0.79)$ ) and FCE on a carcass basis ( $g$ eviscerated carcass weight $-(\mathrm{g}$ initial live weight $\times 0.79) / \mathrm{g}$ food eaten $)$. The factor of 0.79 for estimated initial eviscerated carcass weight was previously determined with eight rats (four male and four female) of similar live weight and age to those used for the assays.

The results were analysed by the slope-ratio technique of Finney (1964) for single assays. Duplicate assays were conducted on three meals (T1, T4 and DR1) to assess the repeatability of the individual estimates.

\section{Chick slope-ratio assay}

Diets. Two batches of MBM were assayed in each experiment. Ten diets were used: the basal diet (blanks), three diets to determine the chicks' response to standard lysine and six for the two protein concentrates (three diets per protein concentrate). The basal diet (Table 2) was formulated using the same wheat and wheat gluten as for the pigs and rats to produce a lysine-deficient $(4 \cdot 7 \mathrm{~g} / \mathrm{kg})$ diet. Additional essential amino acids were added to ensure their adequacy according to the estimates of the (US) National Research Council (1971). In each experiment three levels of lysine were used to determine the chicks' response to standard lysine $(1,2$ and $3 \mathrm{~g} / \mathrm{kg})$ which was obtained by the addition to the basal diet of L-lysine monohydrochloride (anhydrous, $98 \%$ pure; Ajinomoto Co. Inc., Japan). The experimental batches of MBM were incorporated into the basal diets to provide the same three levels of total lysine at the expense of wheat starch. The level of tricalcium phosphate was reduced to make allowance for the calcium and phosphorus in the MBMs. Dietary energy was maintained at $13.33 \mathrm{MJ}$ metabolizable energy $/ \mathrm{kg}$ diet using wheat starch and blended vegetable oil as non-protein energy sources. 
Animals and procedure. The ten diets were arranged in a randomized design with four cages of chicks allocated to each diet. Each cage contained seven 8-d-old female commercial broiler chicks selected for uniformity of weight after a 5-h fast. The cages, which contained electrical brooder elements, were located in a controlled environment room maintained at $23 \pm 2^{\circ}$ and $65 \pm 5 \%$ relative humidity. Fluorescent lighting was supplied between 01.00 and 24.00 hours daily. Each cage had an individual food trough and shared a water trough with one adjacent cage. Diets, which were available at all times, were allocated at random to cages of chicks. On the morning of the 9th day on the experimental diets, the chicks and remaining food were weighed. Chick response was assessed in terms of weight gain/d and FCE ( $g$ weight gain/g food intake). The results for FCE were analysed by the slope-ratio technique of Finney (1964) for multiple assays. The availabilities and their standard errors were calculated.

\section{Chemical analyses}

The techniques used were as reported by Batterham et al. (1986) except for acid-insoluble ash (Vogtmann et al. 1975) and Acid Orange-12 dye-binding procedure (Hurrell et al. 1979).

\section{RESULTS}

Chemical analyses

The chemical compositions of the eight meals are presented in Table 1. Meals T2-T5 had a greater tallow content than $T 1(200 v .91 \mathrm{~g} / \mathrm{kg})$ and a higher gross energy content ( 21 v. $18 \cdot 3 \mathrm{MJ} / \mathrm{kg}$ ). On a $\mathrm{g} / 16 \mathrm{~g}$ nitrogen basis the amino acid profiles of meals T1-T5 were similar except for slightly lower lysine contents in meals T2-T5 relative to T1 $(5 \cdot 2$ v. $5 \cdot 8)$. Meals DR1--DR3 had similar proximate analyses. There was a decline in threonine, cystine, histidine and lysine with increasing processing conditions.

\section{Pig slope-ratio assays}

Performance results of the pigs are presented in Table 3. All pigs remained healthy throughout the experiment although there was a small amount of food rejection by most pigs.

Lean in the ham increased slightly as the level of dietary lysine increased and there was no significant difference between the slopes for each treatment.

Availability of lysine was high in the control meal (T1) (0.97) (Table 7, p. 452) whereas increasing the pressure of processing during the early (T2) and particularly the late (T3) stages reduced availability ( 0.74 and 0.46 respectively). Processing at a final temperature of $125^{\circ}$ for an additional $4 \mathrm{~h}$ (T4) had little effect $(0 \cdot 84)$ on lysine availability whereas at $150^{\circ}$ for $4 \mathrm{~h}(\mathrm{~T} 5)$ availability was greatly reduced $(0 \cdot 38)$.

The digestible energy contents of the diets, as estimated by the acid-insoluble ash technique were $(\mathrm{MJ} / \mathrm{kg}$, air-dry basis): standard lysine diets $13 \cdot 9, \mathrm{~T} 114 \cdot 3, \mathrm{~T} 2$ 14.7, T3 14.6, T4 14.6 and T5 14.2 (SEM 0.14 ; LSD $0.39(P<0.05)$ ). There were no linear or quadratic responses for the individual test proteins $(P>0.05)$.

\section{Rat slope-ratio assays}

Performance results of the rats are presented in Tables 4 and 5 and the slope-ratio estimates for the eight MBMs are presented in Table 7 (p. 452).

Lysine availabilities and standard errors for the duplicate assays for T1, T4 and DR 1 were respectively $0.89(0.09), 0.87(0.10) ; 0.53(0.08), 0.66(0.09) ; 0.64(0.09), 0.69(0.09)$. Only mean values are presented in Table 7 for these meals.

Availability estimates were lower than those of the pig (range $0.88-0.21$ ). Treatment 
Table 3. Carcass gain, food conversion efficiency (FCE) on a carcass basis and lean content of hams of pigs during the 20-50 $\mathrm{kg}$ growth phase when fed on the diets for a slope-ratio assay for lysine in meat and bone meals T1-T5*

\begin{tabular}{|c|c|c|c|c|c|c|}
\hline \multirow{2}{*}{$\begin{array}{l}\text { Lysine } \\
\text { dose } \\
\text { level } \\
(\mathrm{g} / \mathrm{kg})\end{array}$} & \multicolumn{6}{|c|}{ Form of lysine addition } \\
\hline & $\begin{array}{l}\text { Free } \\
\text { lysine }\end{array}$ & $\mathrm{T} 1$ & $\mathrm{~T} 2$ & $\mathrm{~T} 3$ & $\mathrm{~T} 4$ & T5 \\
\hline \multicolumn{7}{|c|}{ Carcass gain $(\mathrm{g} / \mathrm{d}) \dagger$} \\
\hline 0 & 335 & - & - & - & - & - \\
\hline 0.5 & 367 & 382 & 367 & 345 & 376 & 345 \\
\hline $1 \cdot 0$ & 394 & 409 & 386 & 376 & 405 & 377 \\
\hline 1.5 & 432 & 390 & 417 & 353 & 406 & 391 \\
\hline $2 \cdot 0$ & 449 & 451 & 397 & 399 & 446 & 387 \\
\hline $2 \cdot 5$ & 473 & 466 & 449 & 420 & 435 & 385 \\
\hline \multicolumn{7}{|c|}{ SEM $15 \ddagger$} \\
\hline \multicolumn{7}{|c|}{ FCE (carcass basis) $\S$} \\
\hline 0 & $0 \cdot 262$ & - & - & - & - & 一 \\
\hline 0.5 & 0.288 & 0.287 & $0 \cdot 280$ & $0 \cdot 279$ & 0.287 & $0 \cdot 274$ \\
\hline $1 \cdot 0$ & $0 \cdot 300$ & 0.314 & $0 \cdot 296$ & 0.289 & $0 \cdot 307$ & 0.291 \\
\hline $1 \cdot 5$ & 0.323 & 0.310 & 0.313 & $0 \cdot 282$ & 0.311 & 0.295 \\
\hline $2 \cdot 0$ & 0.338 & $0 \cdot 336$ & $0 \cdot 307$ & $0 \cdot 300$ & 0.331 & 0.295 \\
\hline $2 \cdot 5$ & $0 \cdot 350$ & 0.347 & 0.333 & $0 \cdot 313$ & 0.328 & 0.294 \\
\hline \multicolumn{7}{|c|}{ SEM 0.008} \\
\hline \multicolumn{7}{|c|}{ Lean in ham $(\mathrm{g} / \mathrm{kg})$} \\
\hline 0 & 573 & - & - & - & - & - \\
\hline $0 \cdot 5$ & 580 & 558 & 581 & 612 & 568 & 589 \\
\hline $1 \cdot 0$ & 612 & 588 & 586 & 568 & 574 & 588 \\
\hline 1.5 & 606 & 609 & 590 & 590 & 577 & 574 \\
\hline $2 \cdot 0$ & 593 & 608 & 631 & 585 & 577 & 556 \\
\hline $2 \cdot 5$ & 597 & 592 & 592 & 572 & 604 & 568 \\
\hline \multicolumn{7}{|c|}{ SEM 13} \\
\hline
\end{tabular}

* For details, see p. 444.

$\dagger$ Hot carcass weight $(\mathrm{kg})$ - (initial live weight $(\mathrm{kg}) \times 0.69) /$ period $(\mathrm{d})$ on experiment.

\pm Based on ninety-seven degrees of freedom.

$\S$ Hot carcass weight $(\mathrm{kg})$ - (initial live weight $(\mathrm{kg}) \times 0.69) /$ food intake $(\mathrm{kg})$.

effects for temperature were similar to those for the pig whereas the effect of pressure was equally detrimental in both the early (T2) and late (T3) stages $(0.45$ and 0.43 respectively).

Lysine availability in DR2 (0.58) was slightly lower than that in DR1 $(0.67)$ whereas that in DR3 was markedly depressed $(0 \cdot 26)$. The estimates for DR1 and DR2 were lower than those of T1 $(0.88)$ and T4 $(0.59)$ whereas the availability in DR3 was similar to that in T5 $(0 \cdot 21)$.

\section{Chick slope-ratio assays}

Chick performance for the eight MBMs are presented in Table 6 and the slope-ratio estimates in Table 7.

Availability estimates were similar to those for the pig for the control (T1) (0.93) and the two temperature treatments $\left(0.86\right.$ and 0.31 for $125^{\circ}$ (T4) and $150^{\circ}$ (T5) treatments respectively). The chick was less susceptible than the pig to the effect of pressure $(0.78$ and 0.63 for the early- (T2) and late- (T3) stage treatments respectively).

Availability estimates for DR1 (1.00) and DR2 (0.86) were similar to the chick estimates for T1 and T4 whereas the estimate for DR3 $(0.54)$ was higher than that of T5. In all cases the chick estimates for DR1 to DR3 were higher than those from the rat estimates. 
Table 4. Carcass gain $(\mathrm{g} / 14 \mathrm{~d})$ and food conversion efficiency $(F C E)$ on a carcass basis of rats fed on the diets for the slope-ratio assay for lysine in meat and bone meals T1-T4

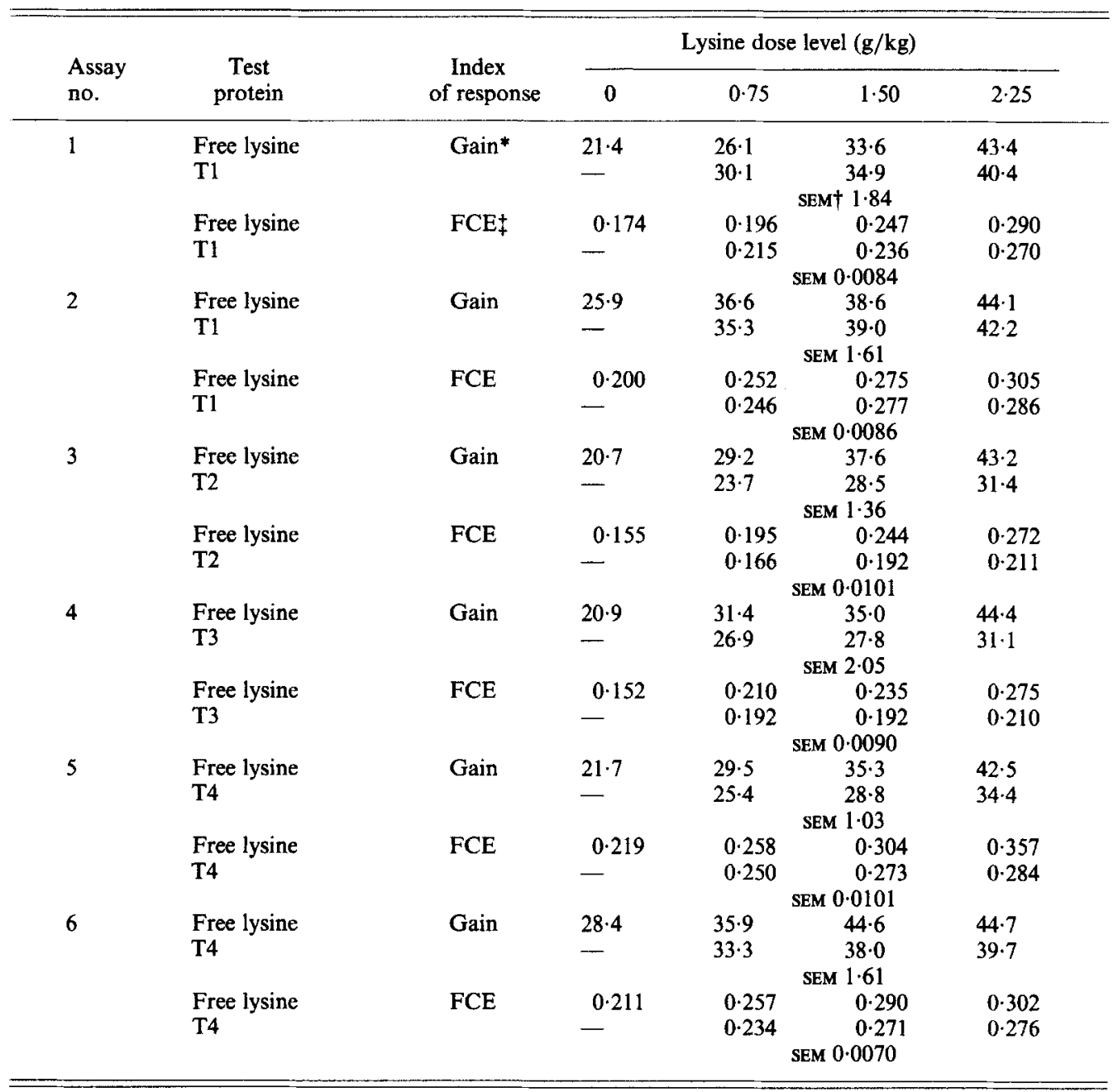

* Eviscerated carcass weight $(\mathrm{g})-$ (initial weight $(\mathrm{g}) \times 0 \cdot 79)$.

$\dagger$ Based on twenty-one degrees of freedom.

$\ddagger$ Eviscerated carcass weight $(\mathrm{g})-$ (initial weight $(\mathrm{g}) \times 0.79) /$ food intake $(\mathrm{g})$.

\section{Chemical 'available' lysine analyses}

The results for the three chemical techniques are presented in Table 7.

The indirect-FDNB estimates for lysine availability ranged from 0.86 in T1 to 0.57 in T5. However, there was little relation between these estimates and the slope-ratio estimates for pigs, rats and chicks for T2, T3 and T4.

The direct-FDNB assay results were in most cases similar to the indirect-FDNB values although there was less differentiation of results for $\mathrm{T} 1$ relative to $\mathrm{T} 3$ and $\mathrm{T} 4$. There appeared little or no relation with the values for Acid Orange-12 dye-binding capacity and the slope-ratio estimates for the three species. 
Table 5. Carcass gain $(\mathrm{g} / 14 \mathrm{~d})$ and food conversion efficiency ( $F C E)$ on a carcass basis of rats fed on the diets for the slope-ratio assay for lysine in meat and bone meals $T 5$ and $D R I-D R 3$

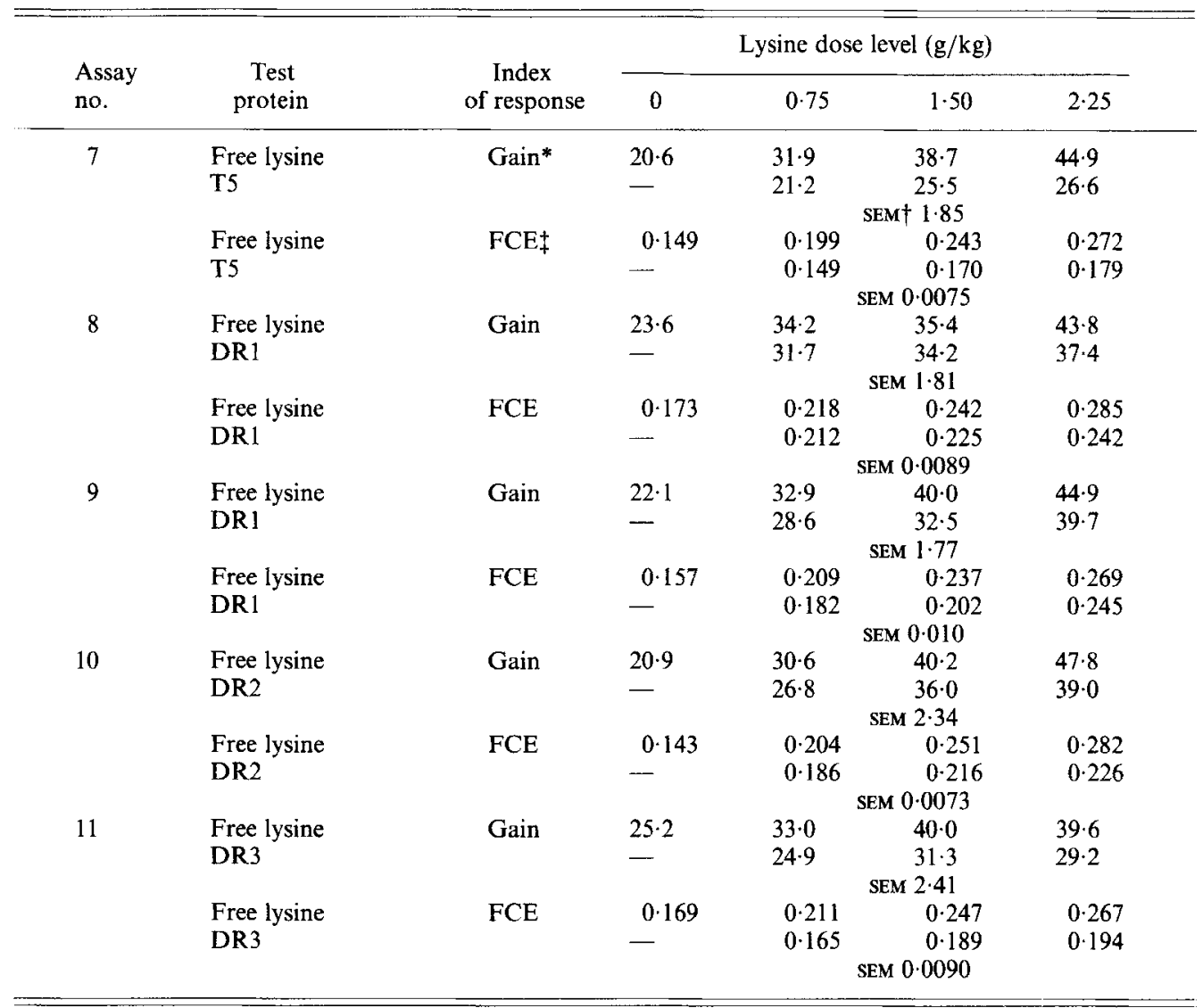

* Eviscerated carcass weight - (initial weight $(\mathrm{g}) \times 0.79$ ).

$\uparrow$ Based on twenty-one degrees of freedom.

$\$$ Eviscerated carcass weight $(\mathrm{g})$ - (initial weight $(\mathrm{g}) \times 0.79)$ /food intake $(\mathrm{g})$.

\section{DISCUSSION}

The results indicate that pressure and temperature have considerable effects on the availability of lysine in MBM and that species susceptibility to these changes varies. For pigs, pressure applied during either the early and particularly during the late stages of rendering reduces availability. Lysine availability was little affected by prolonged exposure to a temperature of $125^{\circ}$ (availability 0.84 ) whereas at $150^{\circ}$ considerable reduction in availability occurred $(0 \cdot 38)$. The magnitude of the processing effects in this experiment is similar to the range in lysine availability in commercial meals previously reported (Batterham et al. 1986).

The slope-ratio estimates for rats indicated lower overall lysine availability in the MBMs compared with the pig. Treatment effects were, however, similar to those found with the pig for those involving temperature (T1, T4 and T5) whereas for pressure, both treatments were equally destructive (T2 and T3). This suggests that rats are more sensitive to the effects 
Table 6. Weight gain $(\mathrm{g} / \mathrm{d})$ and food conversion efficiency $\left(F C E^{*}\right)$ of chicks fed on the diets for the slope-ratio assays for lysine in the meat and bone meals T1-T3 and DRI-DR3

\begin{tabular}{|c|c|c|c|c|c|c|}
\hline \multirow{2}{*}{$\begin{array}{l}\text { Assay } \\
\text { no. }\end{array}$} & \multirow{2}{*}{$\begin{array}{c}\text { Test } \\
\text { protein }\end{array}$} & \multirow{2}{*}{$\begin{array}{l}\text { Index of } \\
\text { response }\end{array}$} & \multicolumn{4}{|c|}{ Lysine dose level $(\mathrm{g} / \mathrm{kg})$} \\
\hline & & & 0 & 1 & 2 & 3 \\
\hline \multirow[t]{8}{*}{1} & Free lysine & Gain & $3 \cdot 29$ & $4 \cdot 21$ & $6 \cdot 73$ & $8 \cdot 15$ \\
\hline & DRI & & - & $4 \cdot 67$ & $6 \cdot 32$ & $7 \cdot 25$ \\
\hline & $\mathrm{T} 1$ & & - & $4 \cdot 27$ & $5 \cdot 84$ & 7.62 \\
\hline & & & \multicolumn{4}{|c|}{ sem 0.335} \\
\hline & Free lysine & FCE & 0.269 & 0.321 & 0.418 & 0.477 \\
\hline & DR 1 & & - & 0.341 & 0.419 & 0.471 \\
\hline & $\mathbf{T} 1$ & & - & 0.325 & 0.403 & 0.467 \\
\hline & & & \multicolumn{4}{|c|}{ SEM 0.0089} \\
\hline \multirow[t]{8}{*}{2} & Free lysine & Gain & $2 \cdot 75$ & 3.81 & $5 \cdot 15$ & 6.44 \\
\hline & DR2 & & - & 3.82 & $5 \cdot 11$ & 5.91 \\
\hline & DR3 & & \multirow{2}{*}{\multicolumn{4}{|c|}{ SEM $0 \cdot 387$}} \\
\hline & & & & & & \\
\hline & Free lysine & $\mathrm{FCE}$ & $0 \cdot 248$ & 0.339 & 0.395 & 0.455 \\
\hline & DR2 & & - & 0.322 & $0 \cdot 382$ & 0.428 \\
\hline & DR3 & & - & 0.315 & 0.330 & 0.369 \\
\hline & & & \multicolumn{4}{|c|}{ SEM 0.0109} \\
\hline \multirow[t]{8}{*}{3} & Free lysine & Gain & $3 \cdot 70$ & $5 \cdot 29$ & $6 \cdot 67$ & 9.04 \\
\hline & $\mathrm{T} 2$ & & - & 4.57 & $6 \cdot 04$ & $7 \cdot 38$ \\
\hline & $\mathrm{T} 3$ & & - & $4 \cdot 36$ & $6 \cdot 18$ & $6 \cdot 24$ \\
\hline & & & \multicolumn{4}{|c|}{ SEM 0.303} \\
\hline & Free lysine & $\mathrm{FCE}$ & 0.277 & $0 \cdot 343$ & 0.405 & $0 \cdot 496$ \\
\hline & $\mathrm{T} 2$ & & - & $0 \cdot 329$ & $0 \cdot 387$ & 0.439 \\
\hline & $\mathrm{T} 3$ & & - & 0.313 & 0.375 & 0.402 \\
\hline & & & \multicolumn{4}{|c|}{ SEM 0.0109} \\
\hline \multirow[t]{8}{*}{4} & Free lysine & Gain & $2 \cdot 45$ & $4 \cdot 29$ & $5 \cdot 19$ & $7 \cdot 21$ \\
\hline & & & - & 3.74 & $5 \cdot 31$ & $6 \cdot 11$ \\
\hline & T5 & & - & 3.58 & $3 \cdot 88$ & $4 \cdot 03$ \\
\hline & & & \multicolumn{4}{|c|}{ SEM 0.359} \\
\hline & Free lysine & FCE & 0.250 & $0 \cdot 353$ & 0.411 & 0.483 \\
\hline & T4 & & - & $0 \cdot 340$ & 0.406 & $0 \cdot 444$ \\
\hline & T5 & & $\ldots$ & 0.327 & 0.328 & 0.325 \\
\hline & & & \multicolumn{4}{|c|}{ SEM 0.0121} \\
\hline
\end{tabular}

* Weight gain (g)/food intake (g).

+ Based on thirty degrees of freedom.

of pressure applied to the MBM than the pig. The results for the duplicate assays for rats for T1, T4 and DR1 indicated good repeatability of the assay values. In previous work (Batterham et al. 1986) little relation between pig and kat responses for some MMs, and MBMs occurred, as found for T2 and T3 in the present study. These differences in response to some forms of amino acid damage limits the value of rat assays for predicting pig responses.

With chicks, the overall effects of temperature on lysine availability were similar in magnitude to those of the pig ( $\mathrm{T} 1 \simeq 0.95, \mathrm{~T} 4 \simeq 0.85, \mathrm{~T} 5 \simeq 0.35$ ). The lack of effect of prolonged heat at $125^{\circ}$ supports earlier work (Bremner, 1976) that temperatures of around $125^{\circ}$ have little effect on protein quality of $\mathrm{MM}$ or MBM for chicks. The higher lysine availabilities with the chick for $\mathrm{T} 2$ and $\mathrm{T} 3$ indicates that the chick is less sensitive to the nature of some forms of heat damage of MBMs than the pig. This supports earlier findings (Major \& Batterham, 1981).

The overall reduction in lysine availability as estimated by the three chemical techniques 
Table 7. Total lysine ( $\mathrm{g} / 16 \mathrm{~g}$ nitrogen) and the availability of lysine (proportion of total) in the meat and bone meals as assessed by three chemical techniques and by the slope-ratio assay with pigs, rats and chicks

(Mean values with their standard errors)

\begin{tabular}{|c|c|c|c|c|c|c|c|c|c|c|}
\hline \multirow{3}{*}{$\begin{array}{l}\text { Meat } \\
\text { and } \\
\text { bone } \\
\text { meal }\end{array}$} & \multirow{3}{*}{$\begin{array}{l}\text { Total } \\
\text { lysine }\end{array}$} & \multicolumn{3}{|c|}{ Chemical assays } & \multicolumn{6}{|c|}{ Slope-ratio assays } \\
\hline & & \multirow{2}{*}{$\begin{array}{c}\text { Indirect- } \\
\text { FDNB } \\
\text { assay }\end{array}$} & \multirow{2}{*}{$\begin{array}{c}\text { Direct- } \\
\text { FDNB } \\
\text { assay }\end{array}$} & \multirow{2}{*}{$\begin{array}{c}\text { Acid } \\
\text { Orange-12 } \\
\text { assay }\end{array}$} & \multicolumn{2}{|c|}{ Pigs } & \multicolumn{2}{|c|}{ Rats } & \multicolumn{2}{|c|}{ Chicks } \\
\hline & & & & & Mean & SEM & Mean & SEM & Mean & SEM \\
\hline $\mathrm{T} 1$ & $5 \cdot 8$ & 0.86 & 0.74 & 0.57 & 0.97 & 0.09 & 0.88 & 0.07 & 0.93 & 0.05 \\
\hline $\mathrm{T} 2$ & $5 \cdot 3$ & 0.72 & 0.64 & 0.65 & 0.74 & 0.08 & 0.45 & 0.08 & 0.78 & 0.05 \\
\hline $\mathrm{T} 3$ & 5.0 & 0.69 & 0.70 & 0.68 & 0.46 & 0.08 & 0.43 & 0.08 & 0.63 & 0.05 \\
\hline $\mathrm{T} 4$ & 5.3 & 0.74 & 0.70 & 0.65 & 0.84 & 0.09 & 0.59 & 0.06 & 0.86 & 0.06 \\
\hline T5 & $5 \cdot 1$ & 0.57 & $0 \cdot 54$ & 0.44 & 0.38 & 0.08 & 0.21 & 0.06 & $0 \cdot 31$ & 0.06 \\
\hline DR1 & $5 \cdot 4$ & 0.81 & 0.80 & 0.69 & - & - & 0.67 & 0.06 & 1.00 & 0.05 \\
\hline DR2 & 4.9 & 0.74 & 0.74 & 0.66 & - & - & 0.58 & 0.08 & 0.86 & 0.06 \\
\hline DR3 & $4 \cdot 5$ & 0.55 & 0.52 & 0.46 & - & - & $0 \cdot 26$ & $0 \cdot 10$ & 0.54 & 0.06 \\
\hline
\end{tabular}

FDNB, 1-fluoro-2,4-dinitrobenzene.

for $\mathrm{T} 5$ compared with $\mathrm{T} 1$ indicates reactions involving the free $\epsilon$-amino group of lysine were one factor reducing availability. However, these reactions appear to be only part of the overall reactions that reduce availability, as the fall in indirect- or direct-FDNB values was only approximately half the decline of biological availability for the pig, rat and chick. This supports the findings of Carpenter (1973). With the responses to T2 and T3 (both pressure) and $\mathrm{T} 4\left(125^{\circ}\right.$ for $\left.4 \mathrm{~h}\right)$ there was less of a relation, suggesting that the changes induced by pressure, particularly, may involve reactions other than those with the $\epsilon$-amino group of lysine. Overall, this lack of agreement between the assays based on FDNB and biological response limits their value as techniques for assessing lysine availability. With the Acid Orange- 12 dye-binding procedure, the lack of sensitivity to treatment effects indicates that the technique has little application in assessing lysine availability or monitoring protein quality of MBMs during processing.

The use of carcass gain to assess response assumes that lean deposition is similar for all treatments or, if it is affected, then the rate of change is similar for all test proteins. In the pig experiment carcass lean, as indicated by lean in the ham, increased with increasing lysine level. However, the rate of increase was similar for all test proteins, thus indicating that carcass gain was an adequate measure of protein deposition. Similarly, although there was some food rejection in Assay 1, the use of food conversion efficiency on a carcass basis as the index of response has the advantage that it takes into account any variation in food intake between treatments.

The range in digestible energy in the diets, as assessed by the acid-insoluble ash technique, was small and would have had little effect on treatment responses. The lower estimated digestible energy content in the standard lysine diets may have resulted in an underestimation of digestibility as a result of difficulties in accurately estimating the low acid-insoluble ash content in the standard lysine diets $(0.68 \mathrm{~g} / \mathrm{kg})$ relative to that in the diets containing MBM (up to $1.6 \mathrm{~g} / \mathrm{kg}$ ).

The rat and chick results for the DR1 to DR3 treatments also indicate differences in species response to heat damage. For rats, lysine availability was lower in DR1 compared with $\mathrm{T} 1(0.67 v .0 .88)$ indicating greater damage by the dry-rendering process relative to 
wet-rendering. For chicks, however, lysine availability was similar for DR1 compared with T1 (1.00 v. 0.93), indicating no differences due to the method of processing. Because of the lack of a relation between the rat and pig results for some treatments, it is not possible to assess whether processing conditions for both techniques would be similar for pigs. However, the small reduction in lysine availability for T4 $\left(0.86 ; 125^{\circ}\right.$ applied for $4 \mathrm{~h}$ after dry-rendering) relative to $\mathrm{T} 1(0.97$; wet-rendered) indicates that any differences would be small.

Overall, the results indicate that the effect of temperature applied to samples of MBM was consistent in the changes in lysine availability induced for pigs, rats and chicks. The effect of temperature in part appeared to be due to reactions involving the free $\epsilon$-amino group of lysine. Consequently, the chemical-FDNB techniques had application in detecting these changes. The application of pressure, however, induced variable reductions in lysine availability for pigs, rats and chicks which appeared less related to reactions involving the free $\epsilon$-amino group of lysine. This limits the interchangeability of results between species and the value of the chemical-FDNB techniques for assessing lysine availability. For all species, there was little relation between lysine availability and dye-binding capacity of the meals, as assessed with the Acid Orange-12 dye-binding procedure, indicating little application of this technique for monitoring protein quality.

The authors thank Mrs L. M. Andersen, Miss B. V. Burnham and Messrs N. R. Thompson, A. W. Davis, R. F. Lowe, T. J. Doolan and H. M. Essery for skilled technical assistance. This work was supported by financial grants from the Australian Pig Industry Research Committee and the Australian Chicken Meat Research Committee.

\section{REFERENCES}

Batterham, E. S. (1973). Estimation of the available amino acid contents of feeds for pigs with Tetrahymena pyriformis $\mathrm{W}$. PhD Thesis, University of Melbourne.

Batterham, E. S., Lowe, R. F., Darnell, R. E. \& Major, E. J. (1986). British Journal of Nutrition 55, 427-440.

Batterham, E. S. \& Murison, R. D. (1981). British Journal of Nutrition 46, 87-92.

Batterham, E. S., Murison, R. D. \& Andersen, L. M. (1984), British Journal of Nutrition 51, 85-99.

Batterham, E. S., Murison, R. D. \& Lewis, C. E. (1979). British Journal of Nutrition 41, 383-391.

Batterham, E. S., Murison, R. D. \& Lowe, R. F. (1981). British Journal of Nutrition 45, 401-410.

Bremner, H. A. (1976). Journal of the Science of Food and Agriculture 27, 307-314.

Carpenter, K. J. (1960). Biochemical Journal 77, 604-610.

Carpenter, K. J. (1973). Nutrition Abstracts \& Reviews 43, 423-451.

Finney, D. J. (1964). Statistical Method in Biological Assay, 2nd ed. London: Griffin.

Herbert, L. S., Dillon, J. F., MacDonald, M. W. \& Skurray, G. R. (1974). Journal of the Science of Food and Agriculture 25, 1063-1070.

Hurrell, R. F., Lerman, P. \& Carpenter, K. J. (1979). Journal of Food Science 44, 1221-1231.

Lewis, D. \& Cole, D. J. A. (1976). Proceedings of the Nutrition Society 35, 87-91.

McCarthy, J. F., Bowland, J. P. \& Aherne, F. X. (1977). Canadian Journal of Animal Science 57, 131-135.

Major, E. J. \& Batterham, E. S. (1981). British Journal of Nutrition 46, 513-519.

National Research Council (1971). Nutrient Requirements of Poultry. 6th ed. Washington, DC: National Academy of Sciences.

National Research Council (1972). Nutrient Requirements of Laboratory Animals, 2nd ed. Washington, DC: National Academy of Sciences.

Roach, A. G., Sanderson, P. \& Williams, D. R. (1967). Journal of the Science of Food and Agriculture 18, $274-278$.

Vogtmann, H., Pfirter, H. P. \& Prabucki, A. L. (1975). British Poultry Science 16, 531-534. 